\title{
Change Detection of Land Cover and Salt Affected Soils at Siwa Oasis, Egypt
}

\author{
Taher, M. H. Yossif 1
}

\begin{abstract}
Constant and accurate change detection of land cover/land use features is highly significant to interpret the correlation between human activities and natural phenomena in order to make better decisions and for investigating the processes and patterns of landscape changes over time and the impact of these changes on sustainable development. Soil salinization is a major problem affecting productivity of irrigated lands. Managing salinity to minimize environmental impact is a prerequisite for sustainable irrigated agriculture. The current study aims at detecting, classifying and mapping the current status for land cover types, salt affected soils and their changes in quantity that have taken place in Siwa Oasis during the period from 1987 to 2017, based on satellite imagery data, GIS facilities, statistical analysis, ground truth and laboratory analysis.
\end{abstract}

An approach of multi-temporal mid resolution satellite images of TM 1987, and OLI 82017 combined with visual interpretation, supervised classification and new remote sensing indices namely NDVI to enhance accuracy of land cover classification was used. The study employed normal image classification, and developing model from ECe vs NDSI to produce maps for salt affected soils during the period under study.

Results showed that the study area has different land cover / land use units; i.e. Salt marches, Sabkha, Cropland, Grassland, Bare Land, Urban, Lakes, Sand dunes, and Hills. During the study period, a very severe land cover change has taken place as a result of mismanagement of land resources. Change detection at the study area explains the rapid increase of saline lakes and salt marshes, and the consequent hazards to the cultivated lands, roads and archeological sites and urban areas over the last three decades. These changes in land cover led to land degradation and water logging in many parts of the study area. In 1987, very slightly saline soil area was the largest in extent $34.1 \%$ of the total area whereas strongly saline, slightly saline and moderately saline soils covered $27.0 \%$, $17.4 \%$ and $17.1 \%$, respectively, of the total area. In 2017 , strongly saline area increased as compared to 1987 and contributed for $39.1 \%$ of the total area, while very slightly, slightly saline and, moderately saline areas represented $18.9 \%$ and $13.2 \%$ and $14.9 \%$ respectively of the total area. Most of the salt affected areas were on shallow water table. The results indicate that long-term irrigation activities would affect agricultural potentiality of the area in the future. RS, GIS, NDVI and NDSI tools are efficient and feasible for detecting land cover/land use and salt affected areas from satellite images.

${ }^{1}$ Pedology dept., Water resources and desert soils division, Desert Research Center, Cairo, Egypt.

Received July 4, 2017, Accepted August 15, 2017
Keywords: Land cover/Land use; Land cover change; Salt affected soils; Remote Sensing; GIS; Salinity Index; Siwa Oasis.

\section{INTRODUCTION}

Analysis of Land Cover and Land Use (LCLU) history is an indispensable basis to land use planning of agricultural development activities, monitoring of food security, and climate related research. Since LCLU dynamics follow complex rules, accurate surveys of both land cover conversion and modification (management changes that affect land cover characteristics but not its overall type) are crucial in LCLU change studies (Lambin et al., 2003). Land cover provides a first indication of a reduction or increase in vegetation, habitat fragmentation and land conversion (UNCCD, 2016). For this purpose, the temporal dynamics of remote sensing data can play an important role in monitoring and analyzing land cover changes. Accurate and up-to-date land cover change information is necessary in understanding and assessing the environmental consequences of such changes (Giri et al, 2005). While remote sensing has the capability of capturing such changes, extracting the change information from satellite data requires effective and automated change detection techniques (Roy et al., 2002).

Digital change detection is the process of determining and/or describing changes in land cover and land use properties based on co-registered multitemporal remote sensing data. The basic premise in using remote sensing data for change detection is that the process can identify change between two or more dates that is uncharacteristic of normal variation. Numerous researchers have addressed the problem of accurately monitoring land cover and land use change in a wide variety of environments (Chan et al., 2001; Muchoney and Haack, 1994; Singh, 1989).

Soil salinization in irrigated lands is becoming an increasing problem affecting global agricultural production and sustainable utilization of land resources, especially in arid and semiarid regions worldwide. According to the FAO, the salt affected soils occupy around 397 million hectares of the world total area (Koohafkan, 2012.). Soil salinity is caused by weathering of rocks and primary mineral formed in situ or transported by water or wind. Other causes are 
topography, excessive irrigation that aggravate water table to rise and bring saline ground water near the land surface (Shrestha, and Farshad, 2008). Thus, soil salinity categories are either primary salinity which is naturally occurring or secondary salinity which is human-induced.

Soil salinization has adverse impacts on plant growth, crop production, soil characteristics, water quality and hydrological, geochemical, social and economic aspects which eventually result in soil erosion and land degradation (Zhu, 2001; Corwin and Lesch, 2003; Rhoades, and Loveday, 1990).

Soil degradation due to salinity is increasing at an alarming rate endangering the agricultural practices (Metternicht, 2003; Astaraei et al., 2008; Zheng et al., 2009; Rongjiang and Jingsong, 2010).

Land degradation, which is the product of a complex interaction of several variables, reduces the potential capability of soils to produce goods and services. Arid and semi-arid regions are under high pressure to produce food owing to their rapidly increasing populations. The consequent changes in land cover and land use mainly due to agricultural intensification together with harsh climatic conditions including global climate change have accelerated land degradation process causing yield reduction in many parts of the arid world. Therefore, the need for detecting salinization and land degradation along with assessing its severity at any given time becomes vital.

To realize sustainable development, establish national land use policy, implementation of soil reclamation programs and preventing any further salinization to maintain agricultural lands and natural ecosystems, information on the spatial extent, nature and distribution of land cover and the trend and the rate of land cover conversion are of great importance.

Therefore, timely detection of land cover in salt affected soils, monitoring and assessment of severity level of land degradation has become very essential on the local and regional scales. Ghabour and Daels (1993) agreed that detecting land cover traditionally is time consuming, but remote sensing data and techniques offer more efficiently and economically rapid tools and techniques for monitoring and mapping land cover types.

Remote sensing data and techniques have been progressively applied to monitor and map land cover degradation since 1960s when black-and-white and color aerial photographs were used to delineate saltaffected soils (Dale, 1986). Multispectral data such as Landsat, Satellite Pour l'Observation de la Terre (SPOT), IKONOS, Quick Bird and the Indian Remote Sensing (IRS) series of satellites, as well as hyperspectrl data such as EO-1 Hyperion and HyMap, proved to be useful in detecting, mapping, and monitoring land cover degradation (Farifteh, 2007; Weng, 2008; Dehni and Lounis, 2012).

The present scattered vegetation or halophytes on the soil surfaces can serve as a sign of the salinity problem, making it possible to indirectly detect and map areas that are affected by soil salinity using the reflectance from vegetation. Different salinity indices were developed to detect and map soil salinity such as Normalized Difference Salinity Index (NDSI) and Salinity Index (SI). Soil salinity can be detected directly from remotely sensed data through salt features that are visible on soil surface, such as bare soil with white salt crusts on the surface (Matinfar, 2013) or indirectly from indicators such as the presence of halophytic plant, the performance level of salt-tolerant crops (Alhammadi and Glenn, 2008; Iqbal, 2011; Aldakheel, 2011).

Spectral reflectance of soils is determined by their physico-chemical properties, in particular humus content, soil texture, types of clay, soil color and iron oxides, carbonates, gypsum, salts and surface roughness (De Jong, 1992; Shrestha et al.,2005). Schmid et al. (2008) found that crusted saline soil reflects strongly in the visible and near-infrared (NIR) bands; moreover, Rao Singh and Sirohi (1994) noted that a crusted saline soil surface is generally smoother than a non-saline surface and exhibits high reflectance in the visible and NIR bands, which has been confirmed by Rao et al. (1995).

Extensive research using satellite imagery for mapping and monitoring soil salinity has been conducted over the last three decades, mostly with multispectral sensors. These include Landsat Thematic Mapper (TM), Landsat Multispectral Scanner System (MSS), Landsat Enhanced Thematic Mapper Plus (ETM+), SPOT, and Advanced Spaceborne Thermal Emission and Reflection Radiometer (Terra-ASTER) (Dwivedi, 2001; Verma et al., 1994). Elnaggar and Noller (2009) used Landsat TM imagery integrated with decision tree analysis (DTA) to map soil salinity in central Malheur County; there was a significant relationship between EC values and reflectance in Landsat bands 1, 2, 3 and 4 as well as the Brightness (BI) index. Maximum likelihood supervised classification was used to classify the image into nonsaline soils $(\mathrm{EC}<4 \mathrm{dS} / \mathrm{m})$ and saline soils, with accuracy of $97 \%$ and $60 \%$ respectively, whereas DTA predicted five classes of soil salinity with an overall accuracy of approximately $99 \%$. Their results indicated that the use of Landsat TM imagery effectively identified bare soils that were characterized by high spectral reflectance due to a high salt content on the 
surface, and the approach of integrating DTA with remote sensing data was more accurate and effective compared to using remote sensing analysis alone.

Katawatin and Kotrapat (2004) investigated the utility and effectiveness of Landsat-7 ETM+ data with different combinations of three sources of ancillary data (topography, geology, and underground water quality) for soil salinity mapping and monitoring. Their results showed that the use of Landsat ETM+ data bands 4, 5 and 7 yielded the most accurate soil salinity map, with $83.6 \%$ overall accuracy. Using multispectral sensors for soil salinity research was also studied by Goossens et al. (1993). The study examined and compared the accuracy of Landsat TM, MSS, and SPOT XS imagery for soil salinity mapping, Landsat TM was optimal for soil salinity mapping.

Zhang (2011) has recently proposed four Soil Adjusted Salinity Indices (SASIs) through the most sensitive bands in a Soil Adjusted Vegetation Index (SAVI) form. For halophyte plants, SASIs produced better results compared to other selected vegetation indices such as the NDVI and SAVI. These results indicate that in highly saline areas that are covered mainly by halophyte plants, SASIs would give superior results, whereas VIs such as NDVI and SAVI would only be proper to assess salinity in low saline areas covered by salt-sensitive plants.

Abbas and Khan (2007) have suggested an integrated approach based on the spatial analysis of both ground and satellite data to assess soil salinity. Remotely sensed data based salinity indices and a Principal Components Analysis (PCA) were developed to detect soil salinity. They concluded that PCA and salinity indices are promising techniques for soil salinity prediction based on satellite images.

Siwa Oasis has suffered from mismanagement of soil and water resources use, arid climate condition, and lack of awareness among farm officials, all these contributed to the existence of several problems i.e. soil salinization, water logging, an increase in the area of saltwater lakes, salt marches, and the area affected by the high ground water table, such problems have considerably affected the process of agricultural development and types of land cover. Soil salinization is one of the most important problems that commonly occur in Siwa Oasis because of the accumulations of soluble salts resulted from the continuous use of irrigation waters containing high or medium quantity of dissolved salts. The ability to determine and monitor land cover and salt affected soils in Siwa Oasis is of great importance to cultivated areas and land use planning for agriculture.

The present investigation aims at detecting, classifying and mapping the current status for land cover types, salt affected soils and their changes in quantity that have taken place in Siwa Oasis during the period from 1987 to 2017 based on satellite imagery data, GIS facilities, statistical analysis, ground truth and laboratory analysis.

\section{Description of the study area}

Siwa Oasis is a natural depression - under the zero contour line - covering an area of around $518.18 \mathrm{~km}^{2}$, it is situated in the north western region of Egypt's western desert and $300 \mathrm{~km}$ southwest of Marsa Matrouh city between longitudes $25^{\circ} 18^{\prime}$ and $25^{\circ} 50^{\prime} \mathrm{E}$, and latitudes $29^{\circ} \quad 05^{\prime}$ and $29^{\circ} 16^{\prime} \mathrm{N}$, (Map 1). The depression is bounded by the escarpment of the Marmarica plateau to the north, which rises to about 100 $\mathrm{m}$ above the depression floor and by another escarpment to the south which is relatively lower than the northern one that is covered with sand dunes. The lowest parts of the depression floor reach $18 \mathrm{~m}$ below sea level and gradually rises to merge with the general desert level.

The depression has eight (8) distinct villages situated from west to east as follows: El Maraqui, Khamisa, Siwa, Aghormi, Qureishet, Abu Shrouf, El Zeitoun and Timeira. Alluvial and Aeolian deposits are the main sediments that characterize the depression forming a thin sheet lies on the depression floor and sand dunes that border the depression to the south. Hydrologically, the depression has two (2) aquifers, the upper one (Miocene formation) and the lower one (Nubian sandstones). The upper aquifer is the major source of irrigation water with a salinity varies from 1500 to $8000 \mathrm{ppm}$, whereas the surface of the lower aquifer is about $600 \mathrm{~m}$ below the ground surface with a salinity ranges from $300 \mathrm{ppm}$ to $700 \mathrm{ppm}$.

Siwa Oasis falls under the extremely arid climate with hot and dry weather in summer and autumn, warm and mild weather in winter and spring. The annual rainfall intensity equals $9.5 \mathrm{~mm} /$ year with a maximum intensity of $2.1 \mathrm{~mm} /$ month in February and almost zero $\mathrm{mm} /$ month in summer months. The mean annual temperature is $21.5^{\circ} \mathrm{C}$ with a maximum of $38^{\circ} \mathrm{C}$ in July and an absolute minimum of $4.1^{\circ} \mathrm{C}$ in January (Egyptian Meteorological Authority, 2009).

The distribution of soil types depends on lithology, relief and ground water level. Soils are classified by Abd El Samie (2000) according to the USDA Soil Taxonomy, USDA Soil Survey Staff. The main soil subgroups are: Aquic Petrocalcids, Aquic Haplocalcids, Typic Haplocalcids, Calcic Aquisalids, Gypsic Aquisalids, Typic Aquisalids, Calcic Haplosalids, Gypsic Haplosalids, Typic Haplosalids, Typic Psammaquents, Lithic Torripsamments, Typic Torripsamments, Aquic Torrifluvents and Typic Torrifluvents. 


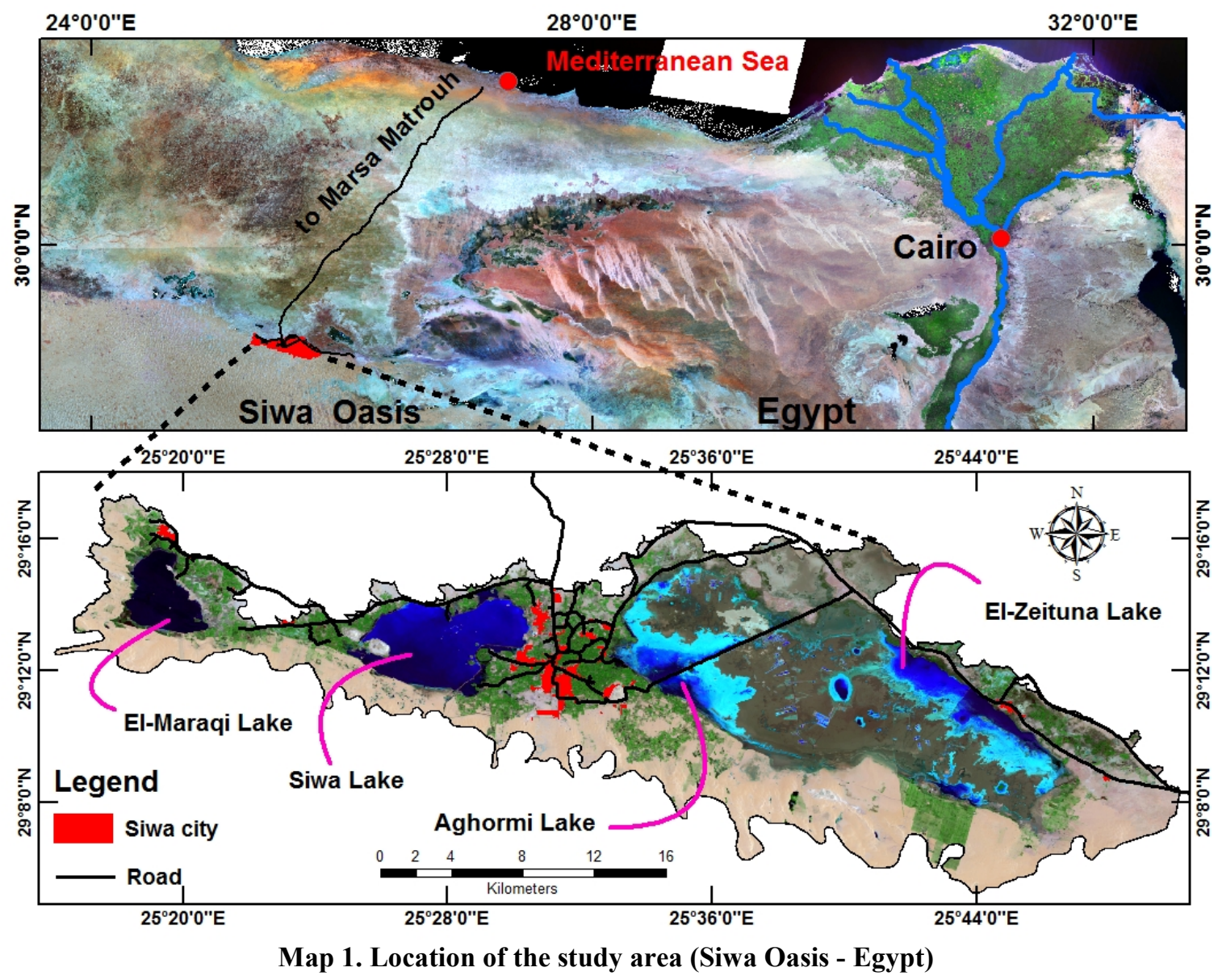

The main cultivated crops in the depression are date palm and olive as cash crops, however; few areas are planted with citrus and some fruit orchards as well as alfalfa as intercropping (Hedia and Abd Elkawy, 2016).

\section{MATERIALS AND METHODS}

-To assess spatial distribution of land cover/use types, and their changes in Siwa Oasis during the period from 1987 to 2017, False Color Composite (FCC) Landsat TM satellite data of 1987, and Landsat 8 OLI 2017 (path 180 and row 40) obtained from USGS (2017) were used, (Figs, 1 and 2). The satellite data were digitally rectified and enhanced using the ERDAS Imagine 9.3. (ERDAS Inc., 2010). Image enhancement was done to improve the visual interpretability of an image by increasing the apparent distinction between the features. The process of visually interpreting of digitally enhanced imagery attempts to optimize the complementary abilities of the human mind in interpreting spatial attributes of images and identifying obscure or subtle features (Lillesand \& Kiefer, 2000). Contrast stretching was applied on the two images and two false color composites (FCC) were produced and visually interpreted using on screen digitizing in order to delineate land cover classes that could be easily interpreted such as urban and sabkha. Some classes were spectrally confused and could not be separated well by supervised classification and hence visual interpretation was required to separate them.

Land cover/land use classes are typically mapped from digital remotely sensed data through the process of a supervised digital image classification with maximum likelihood algorithm which applied in the ERDAS Imagine 9.3 Software (Campbell, 1987; Thomas et al, 1987). The overall objective of the image classification procedure is to automatically categorize all pixels in an image into land cover/land use classes or themes (Lillesand \& Kiefer, 2000). The maximum likelihood classifier quantitatively evaluates both the variance and covariance of the category spectral response patterns when classifying an unknown pixel so that it is considered to be one of the most accurate classifier since it is based on statistical parameters. For better classification results of some indices such as normalized difference vegetation index (NDVI), and normalized difference water index (NDWI) were also applied to 
classify the Landsat images at a resolution of $30 \mathrm{~m}$ in 1987 and 2017.

Supervised classification was done using ground checkpoints and digital topographic maps of the study area. The area was classified into nine main classes i.e. lake water, salt marshes, sabkha, cropland, grassland, bare land, urban, hills and sand dunes.

Then accuracy assessment was carried out using 150 points, 100 checkpoints from field data and 50 points existing on topographic maps dated 1983. The location of the 150 points was chosen using random stratified method to represent different land cover classes of the area. In order to increase the accuracy of land cover mapping of the two images, ancillary data and the result of visual interpretation was integrated with the classification result using GIS in order to improve the classification accuracy of the classified image.

Post-classification change detection technique was applied as the most obvious method of change detection, which requires the comparison of independently produced classified images. Post-classification comparison proved to be the most effective technique, because data from two dates are separately classified, thereby minimizing the problem of normalizing for atmospheric and sensor differences between two dates.

Cross-tabulation analysis was carried out to analyze the spatial distribution of different land cover/use classes and land cover changes. The CROSSTAB module of Arc GIS software was used for performing cross tabulation analysis. CROSSTAB performs two operations. The first is image cross tabulation in which the categories of one image are compared with those of a second image and tabulation is kept of the number of cells in each combination. The result of this operation is a table listing the tabulation totals as well as several measures of association between the images. The second operation that CROSSTAB offers is cross-classification. Cross-classification can be described as a multiple overlay showing all combinations of the logical and operation. The result is a new image that shows the locations of all combinations of the categories in the original images.

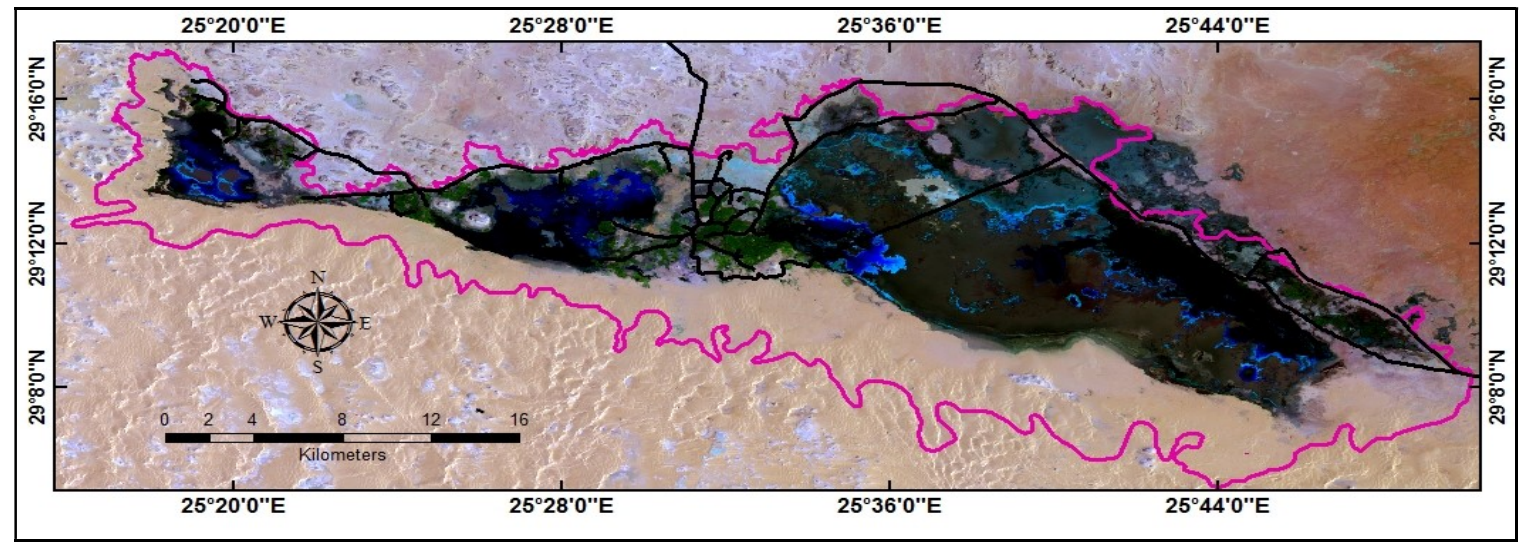

Fig. 1. False color composite Landsat TM image acquired in 1987 (bands 7, 4, 2) of Siwa Oasis, Egypt



Fig. 2. False color composite Landsat 8 OLI image acquired in 2017 (bands 7, 5, 3) of Siwa Oasis, Egypt 
A legend is automatically produced showing these combinations. Cross-classification thus produces a map representation of all non-zero entries in the crosstabulation table.

Six topographic sheets (Egyptian Military Survey Authority, 1983) of 1:50,000 scale pertaining the study area were used for geo-referencing of satellite images, creation of the study area map, validation of the ground truth, generation of different administrative boundaries and transport network. Digital elevation models (SRTM) of 30 meter resolution were also used, USGS (2017).

ERDAS Imagine 9.3 and the ArcGIS 9.3 software were used as the main GIS packages for analyzing, processing and mapping.

-To assess the spatial distribution of ECe and to predict soil salinity level at different locations and their changes of the study area - Siwa Oasis - during the period from 1987 to 2017, regression analysis was made based on measured ECe point data and Normalized Difference Salinity Index (NDSI) generated from Landsat 8 OLI image 2017. For this regression analysis, a total of 77 soil samples (ECe points) were collected from the surface horizon $(0-20 \mathrm{~cm})$ in Jan and Feb, 2017 during soil field survey that covered the study area. The investigation sites were selected depending on the same previous locations done by DRC staff, (2000). The coordinate of locations were registered and imported to GIS software as point map. Soil samples were taken for laboratory analysis. The electrical conductivity (EC) of extract from soil paste was measured according to soil survey laboratory methods manual, USDA (2014b). Attempt was made to predict ECe values at unsampled locations through regression analysis. This was done by distributing the ECe sample points on NDSI generated from Landsat 8 OLI image of 2017 in the ArcMap software (ESRI, 2010). The corresponding value of NDSI for ECe point value was extracted using spatial analyst tool (extract values to points) in the ArcGIS environment, the corresponding ECe values were plotted on scatter diagram and the best fit line and equation were determined (Eq. below). Based on this equation, regression analysis model was developed using model builder in the ArcGIS environment to predict soil salinity level for the whole area in the form of raster map (Maps 7 and 8).

$$
\text { Salinity }=38.92 \mathrm{x}^{2}+31.1 \mathrm{x}+10.6
$$

where $\mathrm{x}$ is spectral reflectance/NDSI.

Finally, validation of the used methods to assess land cover, salt affected soils and their changes were made.

\section{RERSULTS AND DISCUSSION}

\section{A- Land cover/Land use and changes between 1987-} 2017

Supervised classification using all reflective bands of the two images acquired in 1987 and 2017, respectively was carried out using maximum likelihood classifier in the ERDAS Imagine 9.3 Software. Maps 2 and 3 show the results of this classification. In order to enhance the accuracy of land cover/land use mapping of the two images, ancillary data derived from some indices such as Normalized Difference Vegetation Index (NDVI), and Normalized Difference Water Index (NDWI) and the result of visual interpretation were integrated with the classification results using GIS. The module used is the overlay module in Arc GIS software. Through the overlay process, areas which were misclassified in the urban, sabkhas and salt marshes classes were relabeled to the correct classes using the layer of visual interpretation. This overlying of the visual interpretation on the result of the classification led to the increase in the overall accuracies by about 10 percent for both images. This could be explained by the fact that saline lakes are spectrally confused with salt marshes class because saline lakes are surrounded by salt marshes and village buildings are confused with bare land class because these building are made from the surrounding local materials (Korshf). Bare land is also confused with grassland because the area is arid and vegetation is sparse.

Remote sensing data and GIS provide opportunities for integrated analysis of spatial data. Post-classification change detection technique was carried out, through cross-tabulation GIS module, for the classification results of 1987 and 2017 images in order to produce change image (Map 4) and statistical data about the spatial distribution of different land cover changes and non-change areas (Table 1).

The nature of the changes of different land cover classes could be derived from table (1), e.g. cropland covered $45.8 \mathrm{~km}^{2}$ in 1987 and $97.5 \mathrm{~km}^{2}$ in 2017 . Out of the $45.8 \mathrm{~km}^{2}$ that was cropland in $1987,36.5 \mathrm{~km}^{2}$ still cropland in 2017 but $3.37 \mathrm{~km}^{2}$ was converted to sabkha, $0.22 \mathrm{~km}^{2}$ was converted to salt marshes and $2.94 \mathrm{~km}^{2}$ was converted to urban. At the same time the increase of cropland, from 1987 to 2017 , was $1.67 \mathrm{~km}^{2}$ from Sabkha, $4.09 \mathrm{~km}^{2}$ from grassland and $47.51 \mathrm{~km}^{2}$ converted from bare land, $6.8 \mathrm{~km}^{2}$ from sand dunes.

Bare land covering an area of $241.61 \mathrm{~km}^{2}$ in 1987 and $52.82 \mathrm{~km}^{2}$ in 2017 indicating an utilization of $188.79 \mathrm{~km}^{2}$ from the total area but through crosstabulation analysis it was found that $47.51 \mathrm{~km}^{2}$ out of 
the bare land was reclaimed and converted to cropland and $10.94 \mathrm{~km}^{2}$ converted to grass land as well, indicating a positive change not land degradation, only $130.34 \mathrm{~km}^{2}$ (converted to other classes than cropland) was degraded.

Grassland increased from $12.39 \mathrm{~km}^{2}$ in 1987 to 22.4 $\mathrm{km}^{2}$ in 2017 . Out of the $12.39 \mathrm{~km}^{2}$ that was grass land in $1987,4.0 \mathrm{~km}^{2}$ remained grassland in 2017, whereas 4.09 $\mathrm{km}^{2}$ converted to cropland. At the same time $5.32 \mathrm{~km}^{2}$ from Sabkha returned to grassland and about 10.94 from bare land. Saline lake area increased from $16.51 \mathrm{~km}^{2}$ in 1987 to $59.12 \mathrm{~km}^{2}$ in 2017 showing more degradation mostly at the expense of $36.21 \mathrm{~km}^{2}$ of the bare land, $5.01 \mathrm{~km} 2$ of Sabkha, whereas salt marshes area increased from $2.99 \mathrm{~km}^{2}$ in 1987 to $82.35 \mathrm{~km}^{2}$ in 2017 indicating more degradation mostly at the expense of $44.85 \mathrm{~km}^{2}$ of Sabkha and $36.71 \mathrm{~km}^{2}$ of bare land. Sand dune area increased from $56.06 \mathrm{~km} 2$ in 1987 to 90.44 $\mathrm{km}^{2}$ in 2017 due to the sand encroachment on the bare land; meanwhile, sabkha area decreased from 136.92 $\mathrm{km}^{2}$ in 1987 to $101.28 \mathrm{~km}^{2}$ in 2017 , the difference in areas occurred mostly in the forms salt marshes and saline lakes.

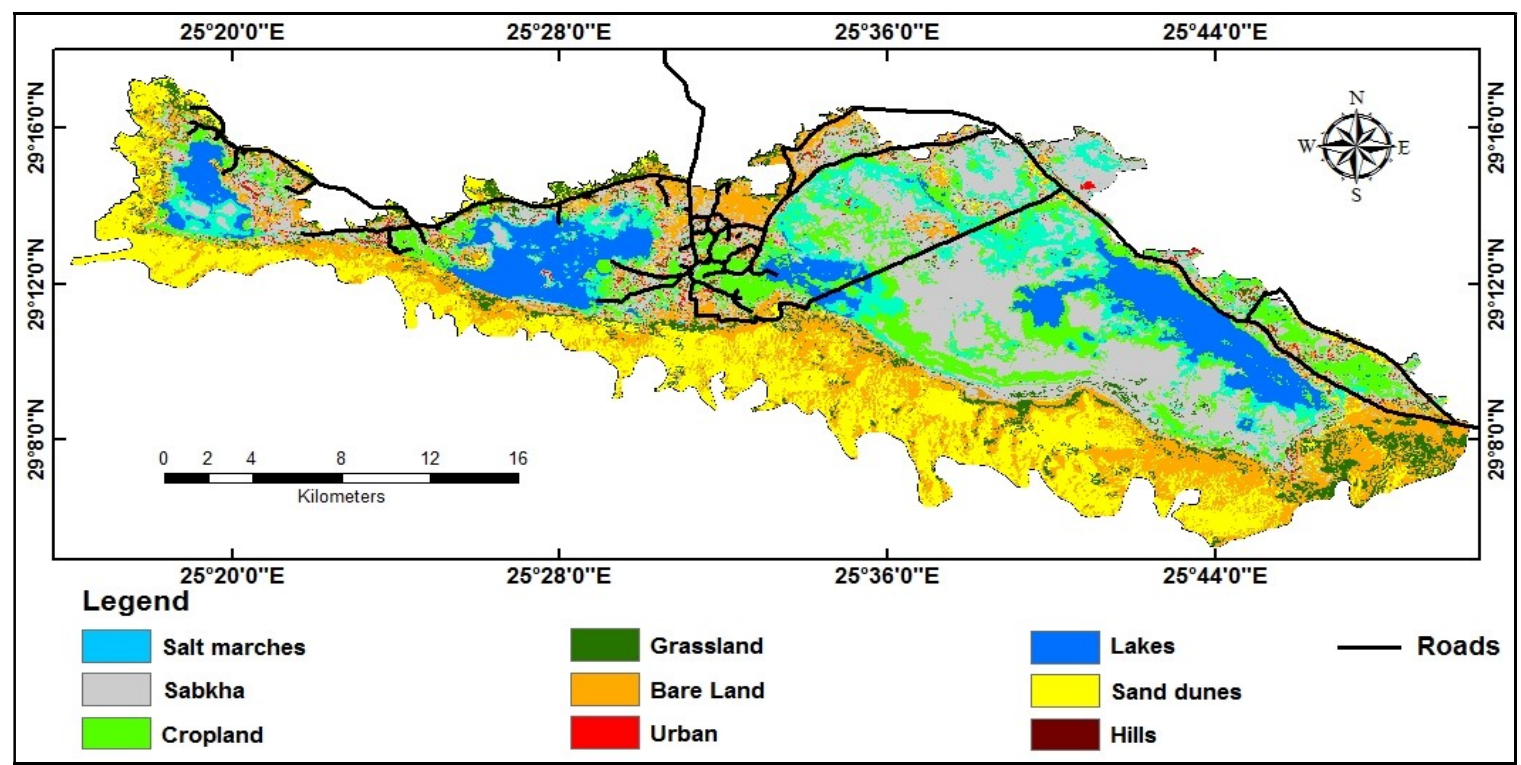

Map 2. Land cover/ land use supervised classification using Landsat TM 1987 for Siwa Oasis, Egypt

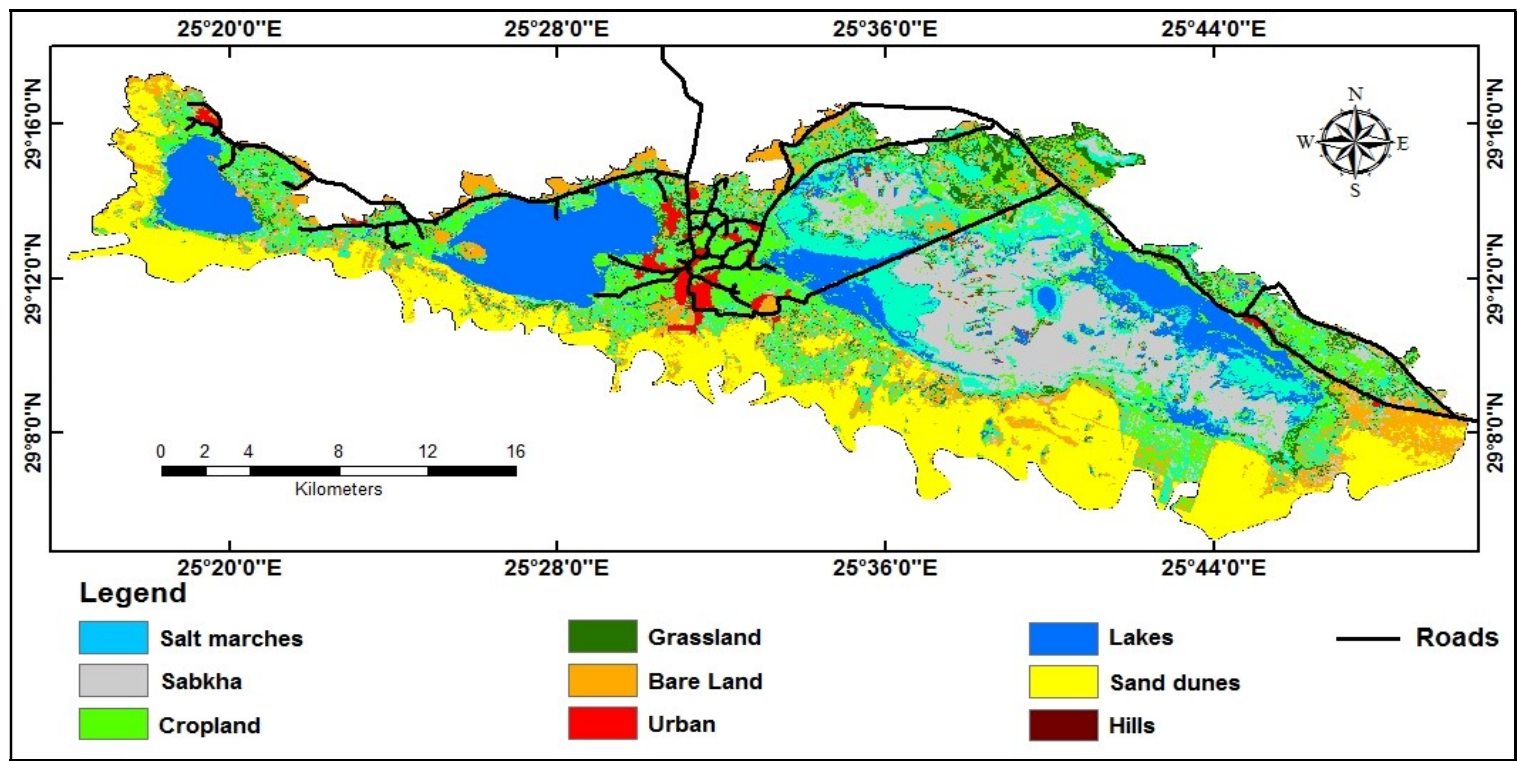

Map 3. Land cover/land use supervised classification using Landsat OLI 2017 for Siwa Oasis, Egypt 


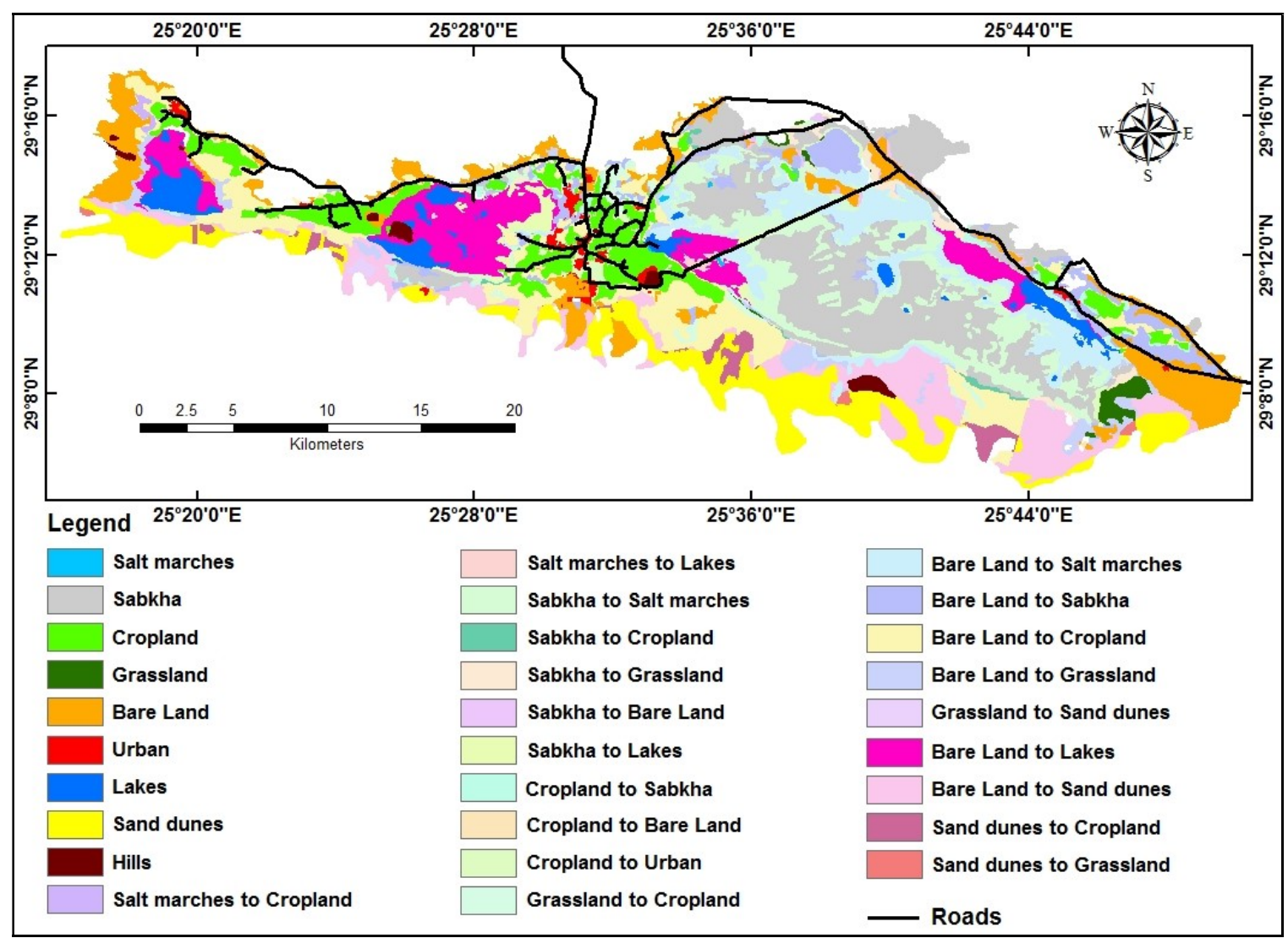

Map 4. Land cover/land use change detection image between 1987 and 2017 for Siwa Oasis, Egypt

Table 1. Cross-tabulation of land cover/land use classes between 1987 and 2017 (area in $\mathrm{km}^{2}$ )

\begin{tabular}{|c|c|c|c|c|c|c|c|c|c|c|c|}
\hline & & \multicolumn{10}{|c|}{1987} \\
\hline & & $\begin{array}{c}\text { Salt } \\
\text { marshes }\end{array}$ & $\begin{array}{l}\text { Sab- } \\
\text { kha }\end{array}$ & $\begin{array}{l}\text { Crop } \\
\text { land }\end{array}$ & Grassland & $\begin{array}{l}\text { Bare } \\
\text { land }\end{array}$ & Urban & $\begin{array}{l}\text { Saline } \\
\text { lakes }\end{array}$ & $\begin{array}{l}\text { Sand } \\
\text { dunes }\end{array}$ & Hills & Total \\
\hline \multirow{10}{*}{ 국 } & Salt marshes & 0.35 & 44.85 & 0.22 & 0.18 & 36.71 & 0.00 & 0.03 & 0.01 & 0 & 82.35 \\
\hline & Sabkha & 0.70 & 77.68 & 3.37 & 1.17 & 18.26 & 0.00 & 0.00 & 0.11 & 0 & 101.28 \\
\hline & Cropland & 0.97 & 1.67 & 36.47 & 4.09 & 47.51 & 0.00 & 0.00 & 6.80 & 0 & 97.51 \\
\hline & Grassland & 0.00 & 5.32 & 1.24 & 4.00 & 10.94 & 0.00 & 0.00 & 0.90 & 0 & 22.40 \\
\hline & Bare land & 0.05 & 1.82 & 0.81 & 1.62 & 48.33 & 0.00 & 0.00 & 0.20 & 0 & 52.82 \\
\hline & Urban & 0.00 & 0.00 & 2.94 & 0.14 & 3.28 & 2.05 & 0.00 & 0.00 & 0 & 8.40 \\
\hline & Saline lakes & 0.93 & 5.01 & 0.50 & 0.00 & 36.21 & 0.00 & 16.48 & 0.00 & 0 & 59.12 \\
\hline & Sand dunes & 0.00 & 0.57 & 0.26 & 1.20 & 40.36 & 0.00 & 0.00 & 48.05 & 0 & 90.44 \\
\hline & Hills & 0.00 & 0.00 & 0.00 & 0.00 & 0.00 & 0.00 & 0.00 & 0.00 & 3.9 & 3.9 \\
\hline & Total & 2.99 & 136.92 & 45.80 & 12.39 & 241.61 & 2.05 & 16.51 & 56.06 & 3.9 & 518.18 \\
\hline \multicolumn{6}{|c|}{$\begin{array}{l}\text { This explains the importance of integrating remote } \\
\text { sensing and GIS in the study of land cover change } \\
\text { detection since it provides essential information about } \\
\text { the nature and spatial distribution of land cover changes. }\end{array}$} & \multicolumn{6}{|c|}{$\begin{array}{l}\text { degradation. The main problems associated with } \\
\text { irrigation schemes are their wasteful use of water, with } \\
\text { application rates exceeding possible plant uptake as well } \\
\text { as poor drainage system and leading to problems } \\
\text { associated with water logging; salinization and } \\
\text { alkalinization. This could be seen on the land cover/land } \\
\text { use map of } 2017 \text { where the salt marshes area has } \\
\text { increased from } 2.99 \mathrm{~km}^{2} \text { in } 1987 \text { to } 82.35 \mathrm{~km}^{2} \text { in } 2017 \text {. } \\
\text { The third land degradation process in the study area is }\end{array}$} \\
\hline
\end{tabular}


wind erosion, which accelerate as a result of the loss of vegetation cover. Wind erosion led to the removal of the relatively fertile topsoil and natural vegetation and this could lead to desertification.

The two false color composite images of 1987 and 2017 were visually interpreted using on screen digitizing to classify the images into different land cover/land use units and detect the changes in the total surface of the study area during the period 1987 - 2017, (Maps 5 and 6). Based on the field observation and measurements resulted from the visual interpretation, it was shown that the change between the image collection dates for the study area was both marked and abrupt in the forms of land cover/land use over the past three decades, (Table 2). Areas of saline lakes (Berket El Zeitun, Berket Aghurmi, Berket Siwa and Berket El Maraqi) across the study area were remarkably expanded from $16.5 \mathrm{~km}^{2}$ (3.2\%) in 1987 to $59.1 \mathrm{~km}^{2}(11.4 \%)$ in 2017 of the total area. Around the saline lakes, the total surface area of salt marches and Sabkha increased from $139.9 \mathrm{~km}^{2}$ $(27.0 \%)$ in 1987 to $183.7 \mathrm{~km}^{2}(35.4 \%)$ in 2017 with a change of $40.6 \mathrm{~km}^{2}$ representing $6.8 \%$ of the total study area. Most of those saline lakes, salt marshes and Sabkhas were not shown on the topographic map of 1983 and only few of them appeared on the image of 1987. Many new roads, urban, cropland and irrigation channels were noticed in the image of 2017 and not that of 1987. The cultivated lands (Hatiat) are represented in the villages: Siwa, Aghormi, Khemisa, and Maraqi villages at variable levels from the floor of the Oasis. A noticeable change is detected in areas of cultivated and reclaimed land in the south and southeastern parts of the study area where part of the bare land and sand dunes were converted to cultivated lands. The total surface area of cropland increased from $45.8 \mathrm{~km}^{2}(8.8 \%)$ in 1987 to $97.5 \mathrm{~km}^{2}(18.8 \%)$ in 2017 , indicating a slight change by $10 \%$ over the last 3 decades. Results of the detected changes at the study area explain the rapid increase of saline lakes and salt marshes, and the consequent hazards to the cultivated lands, roads and archeological sites and urban areas.

The field study exhibited the causes of the increase in salt affected soil and areas of lakes that are attributed to the negative anthropogenic effects i.e. the marked rise in underground water due to the population increase, leakages from water and drainage channels, the annual discharge surplus flowing into lakes expanded the area of saline water causing the formation of salt marshes, shallow water bodies, water logging and soil salinization. In addition, the difference in elevation between cultivated lands and the lakes controls the depth of the drainage water and consequently contributes to the logging problem.
Another reason is the shallow depth of soil-water especially in low lands which leads to quick capillary rise of saline water and soil salinization in the soil profile surface forming salt affected soils e.g. salt marshes and sabkha due to over evaporation considering the effect of location and water absorption capacity, porosity, surface texture and the concentration and combination of salts present.

\section{B- Salt affected soils and their changes between 1987-2017}

The maps of salt affected soils, derived from regression analysis model of ECe vs NDSI of years 1987 and 2017, revealed four classes of salinity levels with different extents of area (Map 7 and 8), viz. very slightly saline, slightly saline, moderately saline and strongly saline soils. Regarding to 1987 , very slightly saline soil area was the largest in extent $\left(176.8 \mathrm{~km}^{2}\right)$, which was $34.1 \%$ of the total area (Table 3 ). Strongly saline soil covered $27.0 \%$ was mainly in the eastern half of the study area. Spatially, they coincided with those derived from visual interpretation, supervised classification and NDSI classification except the variation in the area coverage. Some new patchy areas of strong salinity in the western half of the study area revealed. Slightly saline and moderately saline soils covered $17.4 \%$ and $17.1 \%$, respectively, and found scattered throughout the study area.

Regarding to 2017, strongly saline area increased as compared to 1987 and contributed for $39.1 \%$ of the total area, which concentrated, also, in the eastern part of the study area, while very slightly and slightly saline areas account for $18.9 \%$ and $13.2 \%$, respectively. Which means they have been reduced due to that land resources management were improper. Those areas are characterized by sparse vegetation, shallow water table and low laying landform. Moderately saline areas (14.9\% of the total area) were concentrated in the central part of the study area, where water table level was moderate to shallow, characterized by low laying lands adjacent to and along the shore of Lakes Aghurmi and El Zaitona.

The regression analysis model of ECe vs NDSI offered $74.9 \%$ coefficient determination $\left(\mathrm{R}^{2}\right)$. Most of the measured ECe points concentrated in the upper part of the NDSI value (Fig. 3), but some of the NDSI values indicated low level of salinity in the area. The test for validity of regression analysis model showed high correlation $(69.5 \%)$ between measured ECe value and salinity derived from the model (Fig. 4). Hence, prediction of salt affected areas can be executed using the regression analysis model of ECe vs NDSI. 
Table 2. Area and percentage of change of different land cover classes of 1987 and 2017 classified images

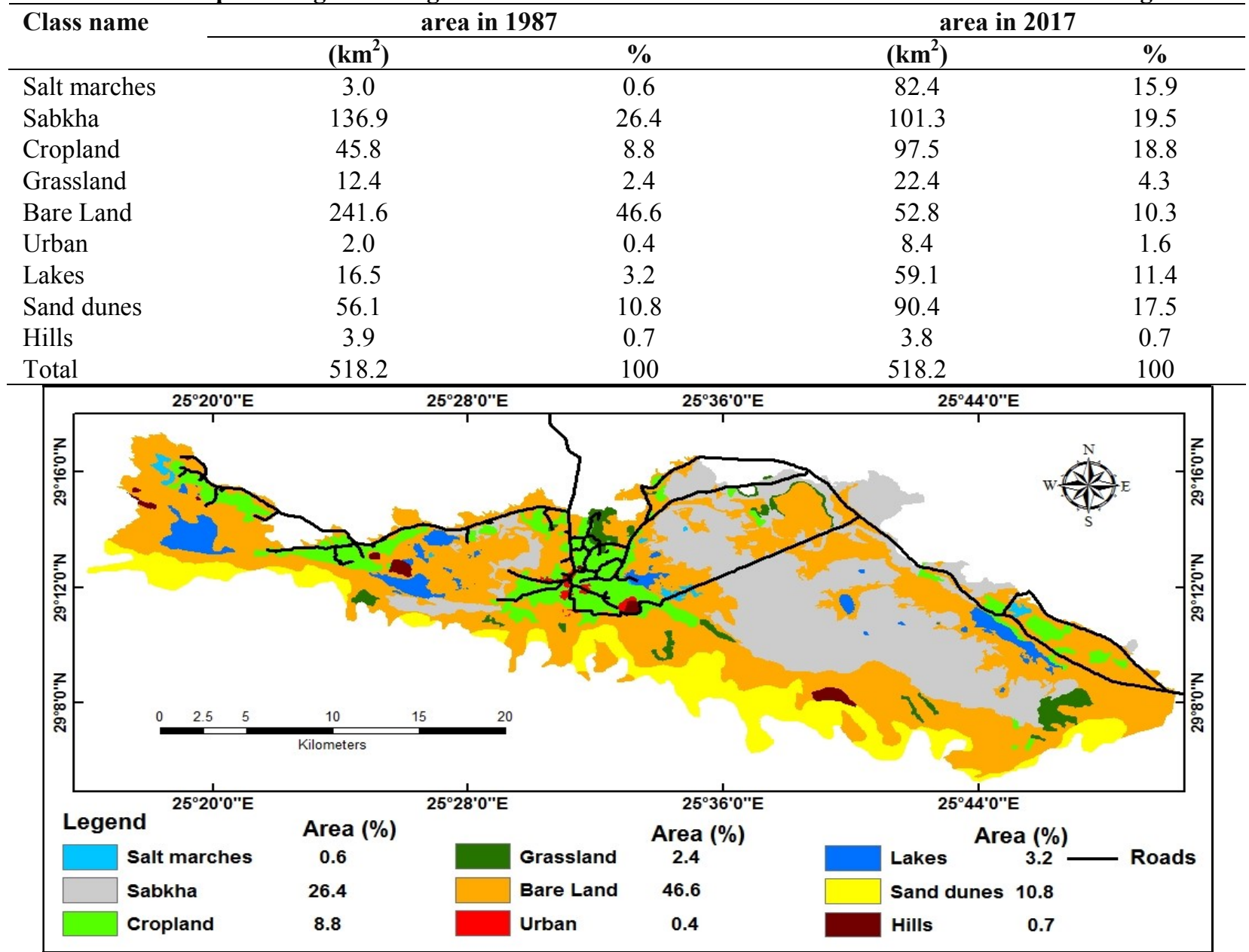

Map 5. Land cover/land use classes as visually interpreted via screen digitizing using FCC Landsat TM 1987 for Siwa Oasis, Egypt

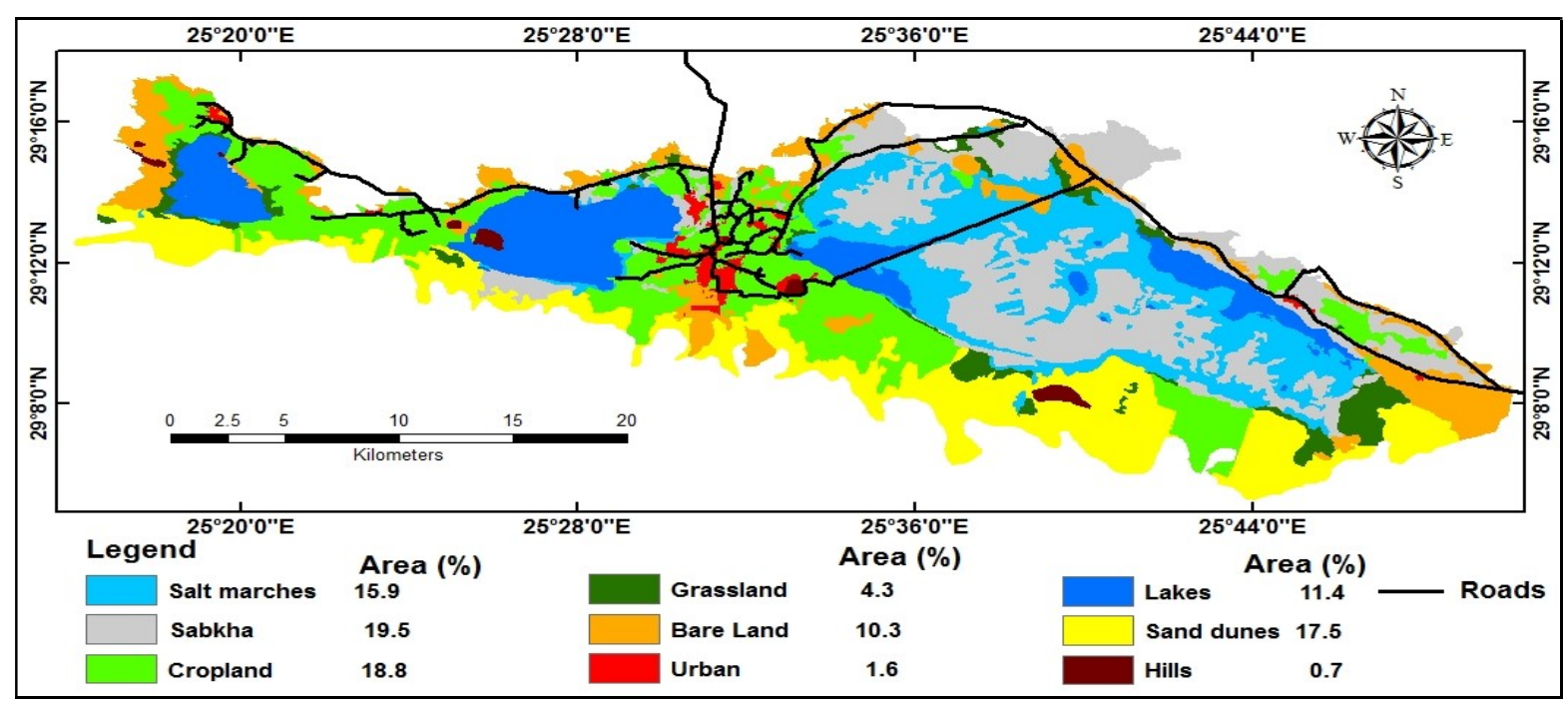

Map 6. Land cover/land use classes as visually interpreted via screen digitizing using FCC Landsat 8 OLI 2017 for Siwa Oasis, Egypt 
Direct validation from the field with supporting photos showed the salinity status in the study area. Crystalline salts were clearly seen on the land surface in some of the areas (Fig. 5). As a result, currently, most of these areas are abandoned from cultivation, whereas nearby areas are left as bare land and some areas are converted to saline lake, salt marches and Sabkha.

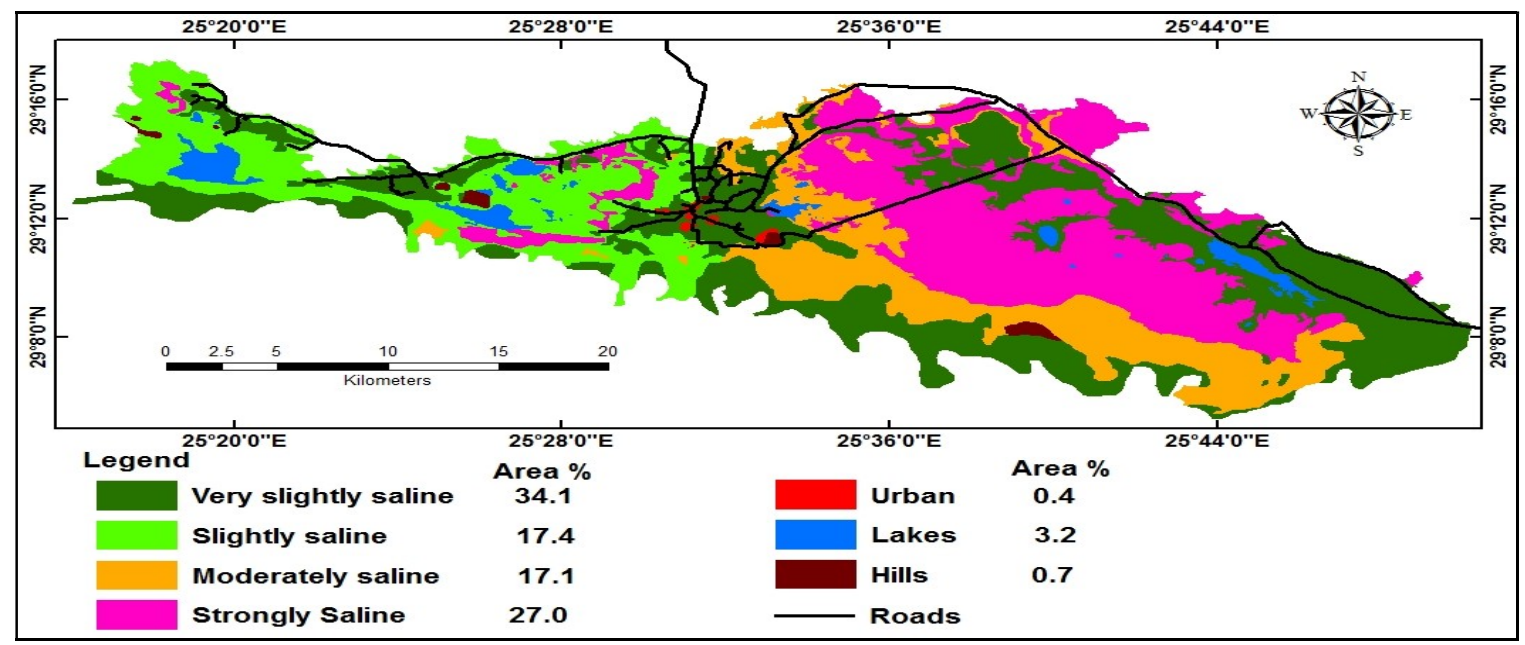

Map 7. Salt affected soil map derived from soil $\mathrm{EC}_{\mathrm{e}} \mathrm{vs}$ NDSI model of Year 1987

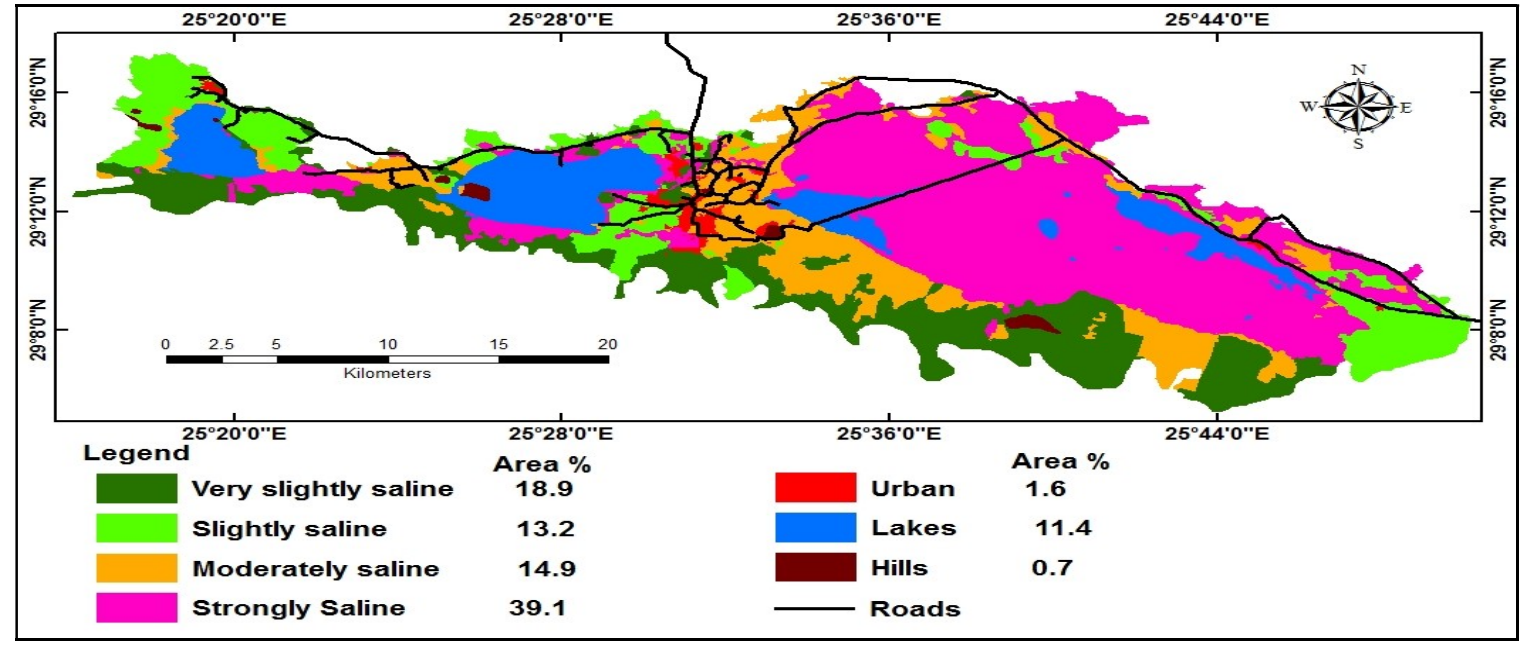

Map 8. Salt affected soil map derived from soil $\mathrm{EC}_{\mathrm{e}}$ Vs NDSI model of Year 2017

Table 3. Area extent of soil salinity level derived from NDSI

\begin{tabular}{llcccc}
\hline Salinity level $\mathbf{( d S} / \mathbf{m})$ & Salinity class & \multicolumn{2}{c}{ Area in $\mathbf{1 9 8 7}$} & \multicolumn{2}{c}{ Area in2017 } \\
\cline { 3 - 6 } & & $\mathbf{( k m}^{\mathbf{2}} \mathbf{( \% )}$ & $\mathbf{( \mathbf { k m } ^ { 2 } )}$ & $\mathbf{( \% )}$ \\
\hline$<4$ & Very slightly saline & 176.8 & 34.1 & 98.1 & 18.9 \\
$4-8$ & Slightly saline & 90.3 & 17.4 & 68.6 & 13.2 \\
$8-16$ & Moderately saline & 88.7 & 17.1 & 77.3 & 14.9 \\
$>16$ & Strongly Saline & 139.9 & 27.0 & 202.7 & 39.1 \\
& Urban & 2.0 & 0.4 & 8.4 & 1.6 \\
& Lakes & 16.5 & 3.2 & 59.1 & 11.4 \\
Total & Hills & 3.9 & 0.7 & 3.9 & 0.7 \\
\hline
\end{tabular}




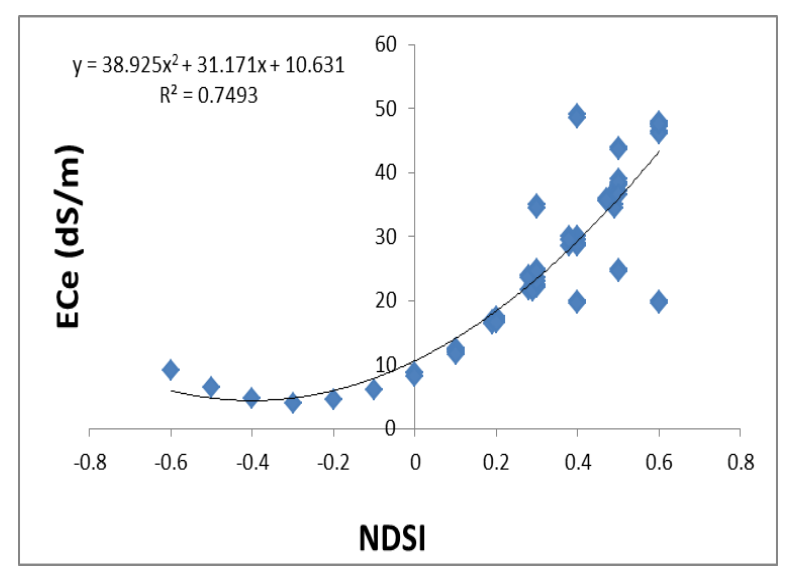

Fig. 3. Regression analyses model between ECe and NDSI

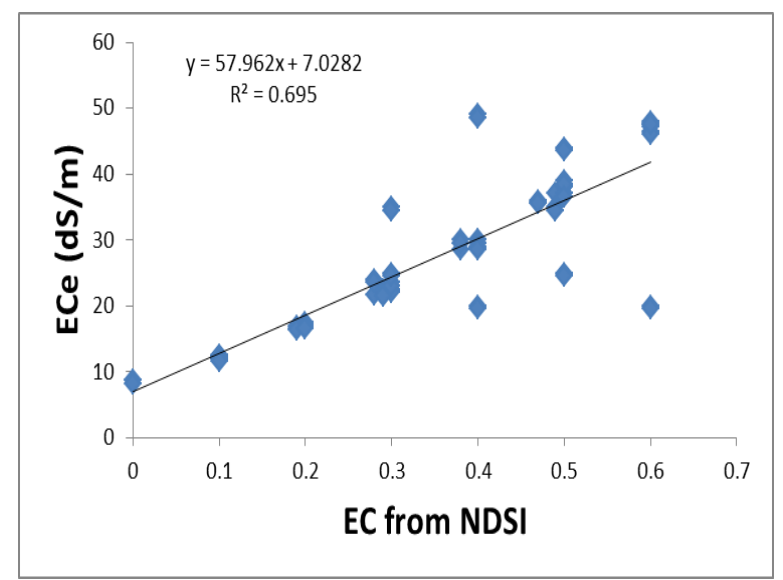

Fig. 4. Correlation between measured ECe vs NDSI

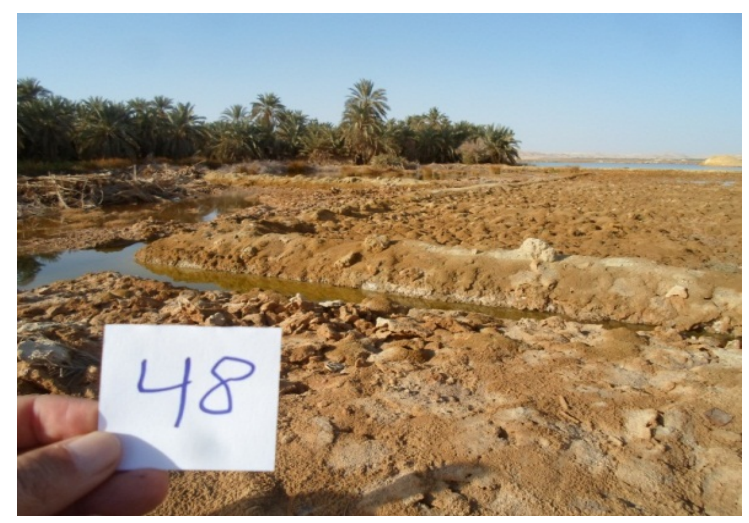

Fig. 5. Surface salt crystals spread around the old cultivated land due to the influence of saline lakes in the study area

\section{CONCLUSIONS}

This study dealt mainly with detecting, classifying and mapping the current status for land cover types, salt affected soils and their changes in quantity that have taken place in Siwa Oasis during the period from 1987 to 2017 based on satellite imagery data, GIS facilities, statistical analysis, ground truth and laboratory analysis.
The present study indicates the following;

1-The study area has different land cover / land use units; i.e. Salt marches, Sabkha, Cropland, Grassland, Bare Land, Urban, Lakes, Sand dunes, and Hills.

2-It was found that integrating visual interpretation with supervised classification led to an increase in the overall accuracy of mapping. 
3-The cultivated areas have been under irrigated agricultural practice more than the last three decades with improper management of the land, which be the cause for the soil salinization and water logging in the study area.

4-Change detection at the study area explains the rapid increase of saline lakes and salt marshes, and the consequent hazards to the cultivated lands, roads and archeological sites and urban areas.

5-For a better management of salt affected soils, soil salinity needs to be monitored and mapped, and prediction of salt affected areas can be made using the regression analysis model developed from ECe vs NDSI.

6-The regression analysis model directly gives the salinity level at any point in the image. Hence, determining the spatial soil salinity potential of Siwa Oasis area and other areas by integrating RS, GIS functionalities and using regression analysis model are crucial. It is a rapid and reliable method of obtaining information on the spatial distribution of salinity.

7-Water table is one of the most important factors, where salts present in the soil are moved with soil moisture through capillary actions and become a source of saline soil formation when water table is close to the soil surface and evaporation rate is high. This indicates that shallow water table and low laying landforms are largely contributing to soil salinity.

8-Changes in the salinity levels with reference to the image collection dates for the study area are revealed in the present study area.

9-Integration of remote sensing with traditional soil surveys and GIS functionalities and using regression analysis model leads toward a more accurate approach of digital soil salinity mapping.

10-Soil salinity maps made for the years 1987 and 2017 have revealed occurrence of salinity in the study area, including variations in the extent of area coverage of the salinity classes.

11-RS and GIS as tools are efficient and time saving for mapping and prediction of soil salinity by applying regression analysis model. The regression analysis model used in this study show that significant extent of area is affected with salt. The regression analysis model is considering a good and efficient method for detecting salt affected areas from satellite images, and hence can be used in similar areas that experience salinization problems.

12-Remote sensing using Landsat TM and OLI data, coupled with image processing techniques are expected to provide effective and efficient means for inventory and monitoring the extent of land cover/land use and salt affected soils.

13-Utilizing vegetation indices (NDVI) in the assessment and mapping of land cover / land use in areas of densely vegetated soils will yield promising results, whereas on bare soils, the identification of salt based on vegetation indices will not work. Thus, soil salinity indices will be the appropriate method in the case of bare soils or soils with very low scattered vegetation cover, providing super results.

14-Soil salinity indices exhibited higher correlations with EC.

15-The main causes of land degradation in the study area are salinization, water logging and sand dunes encroachment. This problem needs to be seriously studied, through multi-dimensional fields including socioeconomic, in order to preserve the newly reclaimed land and increase food production.

\section{REFERENCES}

Abbas, A. and S. Khan, 2007. "Using Remote Sensing Techniques for Appraisal of Irrigated Soil Salinity,” In: L. Oxley and D. Kulasiri, Eds., International Congress on Model- ling and Simulation (MODSIM), Modelling and Simula- tion Society of Australia and New Zealand, Brighton, pp. 2632-2638.

Abd El Samie, M. K. A. 2000. Classification and evaluation of Siwa Oasis soils. Ph. D. Thesis, Fac. Of Agric., Ain Shams Univ.

Aldakheel, Y. Y. 2011. "Assessing NDVI Spatial Pattern as Related to Irrigation and Soil Salinity Management in AlHassa Oasis, Saudi Arabia," Journal of the Indian So-ciety of Remote Sensing, Vol. 39, No. 2, pp. 171- 180. http://dx.doi.org/10.1007/s12524-010-0057-z

Alhammadi, M. S. and E. P. Glenn, 2008. "Detecting Date Palm Trees Health and Vegetation Greenness Change on the Eastern Coast of the United Arab Emirates Using SAVI," International Journal of Remote Sensing, Vol. 29, No. 6, pp. 1745-1765. http://dx.doi.org/10.1080/01431160701395195

taraei, A. R., S.H. Sanaeinejad, M.P. Mir Hosseini, M. Ghaemi, and A. Keshavarzi, 2008. Evaluation of Vegetation cover and soil indices for saline land classification in Neyshabour Region using ETM+ Landsat. International Symposium on Geoinformatics for Spatial Infrastructure Development in Earth and Allied Sciences. 73 78.

Campbell, J. B. 1987. Introduction to remote sensing. The Guilford Press.

Chan, J. C., K. P. Chan, and A. G. O. Yeh, 2001. Detecting the nature of change in an urban environment: A comparison of machine learning algorithms. Photogrammetric Engineering and Remote Sensing, 67, 213-225. 
Corwin, D. and S. Lesch, 2003. "Application of Soil Electrical Conductivity to Precision Agriculture," Agronomy Journal, Vol. 95, No. 3, pp. 455-471. http://dx.doi.org/10.2134/agronj.0455

Dale, P. 1986. "Classification of Reflectance on Colour Infrared Aerial Photographs and Sub-Tropical Salt-Marsh Vegetation Types," International Journal of Remote Sensing, Vol. 7, No. 12, pp. 1783-1788. http://dx.doi.org/10.1080/01431168608948968

Dehni A. and M. Lounis, 2012. "Remote Sensing Techniques for Salt Affected Soil Mapping: Application to the Oran Region of Algeria," Procedia Engineering, Vol. 33, pp. 188-198. http://dx.doi.org/10.1016/j.proeng.2012.01.1193

De Jong, S. 1992. "The Analysis of Spectroscopical Data to Map Soil Types and Soil Crusts of Mediterranean Eroded Soils," Soil technology, Vol. 5, No. 3, pp. 199-211. http://dx.doi.org/10.1016/0933-3630(92)90022-S

DRC staff, 2001. Internal report for scientific program on Monitoring the current state of the cultivated land in Siwa Oasis, DRC, Cairo, Egypt.

Dwivedi, R. S. 2001. "Soil Resources Mapping: A Remote Sensing Perspective," Remote Sensing Reviews, Vol. 20, No. 2, pp. 89-122. http://dx.doi.org/10.1080/02757250109532430

Egyptian Military Survey Authority, 1983. Topographic map of Siwa and other, scale 1:50000, Egyptian Military Survey Authority.

Egyptian Meteorological Authority. (2009). Climate Atlas of Egypt - El-Minia station, Cairo, Egypt.

Elnaggar, A. A. and J. S. Noller, 2009. "Application of Remote- Sensing Data and Decision-Tree Analysis to Mapping Salt- Affected Soils over Large Areas," Remote Sensing, Vol. 2, No. 1, 2009, pp. 151-165, http://dx.doi.org/10.3390/rs2010151

ERDAS Inc. (2010). ERDAS Field Guide (ERDAS Imagine). Eight Edition. Atlantic, Georgia, USA.

ESRI, 2010. Arc GIS Spatial Analyst: Advanced-GIS Spatial Analysis Using Raster and vector data , ESRI, 380 New york, USA.

Farifteh, J. 2007. "Imaging Spectroscopy of Salt-Affected Soils: Model-Based Integrated Method," International Institute Geo-Information Science and Earth Observation (ITC) and Utrecht University, Utrecht,

Ghabour, T. and L. Daels, 1993. "Mapping and Monitoring of Soil Salinity of ISSN," Egyptian Journal of Soil Science, Vol. 33, No. 4, pp. 355-370.

Giri, C., Z. Zhu, \& B. Reed, 2005. A comparative analysis of the Global Land Cover 2000 and MODIS land cover data sets. Remote Sensing of Environment, 94, 123-132.

Goossens, R., M. El Badawi, T. Ghabour, and M. De Dap-Per, 1993. "A Simulation Model to Monitor the Soil Salinity in Irrigated Arable Land in Arid Areas Based upon Remote Sensing and GIS," EARSEL. Advances in Remote Sensing, Vol. 2, No. 3, pp. 165-171.
Hedia R. M. R. and O. R. Abd Elkawy, 2016. "Assessment of Land Suitability for Agriculture in the Southeastern Sector of Siwa Oasis". Alexandria Science Exchange Journal, Vol. 37, No.4, pp 771 - 780.

Iqbal, F. 2011. "Detection of Salt Affected Soil in Rice-Wheat Area Using Satellite Image," African Journal of Agricultural Research, Vol. 6, No. 21, pp. 4973-4982.

Katawatin, R. and W. Kotrapat, 2004. "Use of LANDSAT-7 ETM+ with Ancillary Data for Soil Salinity Mapping in Northeast Thailand," Third International Conference on Experimental Mechanics and Third Conference of the Asian, Sevilla, pp. 708-716.

Koohafkan, P. 2012. "Water and Cereals in Dry lands," The Food and Agriculture Organization of the United Nations and Earth scan, Rome,

Lambin, E. F., H. J. Geist, E. Lepers, 2003. Dynamics of landuse and land- cover change in tropical regions. Annu. Rev. Environ. Resour. 28, 205-241.

Lillesand, T.M., and R.W. Kiefer, 2000. Remote sensing and image interpretation. John Wiley \& Sons, New York.

Matinfar, H. R., S. Kazem Panah, F. Zand, K. Khodaei, 2013. "Detection of Soil Salinity Changes and Mapping Land Cover Types Based upon Remotely Sensed Data," Arabian Journal of Geosciences, Vol. 6, No. 3, pp. 913-919.

Metternicht, G.I., 2003. Remote sensing of soil salinitypotentials and constraints. J. Remote Sens. Environ. 85, $1-20$.

Muchoney, D. M. and B. Haack, 1994. Change detection for monitoring forest defoliation. Photogrammetric Engineering and Remote Sensing, 60, pp. 1243-1251.

Rao Singh . P. and A. Sirohi, 1994. "Spectral Reflectance Proper-ties of Different Types of Soil Surfaces," ISPRS Journal of Photogrammetry and Remote Sensing, Vol. 49, No. 4, pp. 34-40. http://dx.doi.org/10.1016/0924-2716 (94)90045-0

Rao, B. R. M., R. C. Sharma, T. Ravi Sankar, S. N. Das, R. S. Dwivedi, S. S. Thammappa, and L. Venkataratnam, 1995. "Spectral Behaviour of Salt-Affected Soils," International Journal of Remote Sensing, Vol. 16, No. 12, pp. 21252136. http://dx.doi.org/10.1080/01431169508954546

Rhoades, J. and J. Loveday, 1990. "Salinity in Irrigated Agriculture," In: B. A. Stewart and D. R. Nielsen, Eds., American Society of Civil Engineers, Irrigation of Agricultural Crops, Vol. 30, Monograph, American Society of Agronomists, Madison, pp. 1089-1142.

Rongjiang, Y. and Y. Jingsong, 2010. Quantitative evaluation of soil salinity and its spatial distribution using electromagnetic induction method. Agric. Water Manag. 97, pp.1961-1970.

Roy, D. P., P. E. Lewis and C. O. Justice, 2002. Burned area mapping using multi-temporal moderate spatial resolution data bi-directional reflectance model-based expectation approach. Remote Sensing of Environment, 83, 263-286. 
Schmid, T., M. Koch, and J. Gumuzzio, 2008. "Application of Hyperspectral Imagery to Soil Salinity Mapping," In: G. Metternicht and J. Zinck, Eds., Remote Sensing of Soil Salinization: Impact on Land Management, CRC Press, Boca Raton, pp. 113-137.

Singh, A. 1989. Digital change detection techniques using remotely sensed data. International Journal of Remote Sensing, 10, 989-1003.

Shrestha, D., D. E. Margateb, F. van der Meera, and H. V. Anhc, 2005. "Analysis and Classification of Hyperspectral Data for Mapping Land Degradation: An Application in South-eastern Spain," International Journal of Applied Earth Observation and Geoinformation, Vol. 7, No. 2, pp. 85-96. http://dx.doi.org/10.1016/j.jag.2005.01.001

Shrestha, D. P. and A. Farshad, 2008. "Chapter 13. Mapping Salinity Hazard: An Integrated Application of Remote Sensing and Modeling-Based Techniques," In: G. Metternicht and J. A. Zinck, Eds., Remote Sensing of Soil Salinization: Impact on Land Management, CRC Press, Boca Raton. p.257. http://dx.doi.org/10.1201/9781420065039.pt3

Singh, R. P. and A. Sirohi, 1994. "Spectral Reflectance Proper-ties of Different Types of Soil Surfaces," ISPRS Journal of Photogrammetry and Remote Sensing, Vol. 49, No. 4, pp. 34-40. http://dx.doi.org/10.1016/09242716(94)90045-0

Thomas, I. L., V. M. Benning and N. P. Ching, 1987. Classification of remotely sensed images. Bristol: Adam Hilger.
UNCCD, 2016. Land Degradation Neutrality Target Setting. A technical guide. Draft for consultation during the Land Degradation Neutrality Target Setting Programme inception phase.

USDA, Soil Survey Staff. 2014a. Key's to Soil Taxonomy. A basic system of soil classification for making and interpreting soil surveys, U.S. Department of Agriculture, Natural Resources Conservation Service, U.S.D.A.

USDA, Soil Survey Staff. 2014b. Kellogg Soil Survey Laboratory Methods Manual. Soil Survey Investigations Report No. 42, Version 5.0. R. Burt and Soil Survey Staff (ed.).U.S. Department of Agriculture, Natural Resources Conservation Service.

USGS, 2017. Earth Explorer. http://earthexplorer.usgs.gov/ (acces-sed 05.04.15).

Verma, K., R. K. Saxena, A. K. Barthwal, and S. N. Deshmukh, 1994. "Remote Sensing Technique for Mapping Salt Af- fected Soils," International Journal of Remote Sensing, Vol. 15, No. 9, pp. 1901-1914. http://dx.doi.org/10.1080/01431169408954215

Weng, Y. 2008. "Soil Salt Content Estimation in the Yel-low River Delta with Satellite Hyperspectral Data," Ca-nadian Journal of Remote Sensing, Vol. 34, No. 3, pp. 259-270.

Zheng, Z., F. Zhang, F. Ma, X. Chai, Z. Zhu, J. Shi, and S. Zhang, 2009. Spatiotemporal changes in soil salinity in a drip-irrigated field. Geoderma 149, 243-248.

Zhang, T. T. 2011. "Using Hyperspectral Vegetation Indices as a Proxy to Monitor Soil Salinity," Ecological Indicators, Vol. 11, No. 6, pp. 1552-1562.

Zhu, J. K. 2001. "Plant Salt Tolerance," Trends in Plant Science, Vol. 6, No. 2, pp. 66-71. http://dx.doi.org/10.1016/S1360-1385(00)01838-0 


\section{الملخص العربي}

\section{رصد تغير الغطاء الأرضى والأراضى المتأثرة بالاملاح بواحة سيوة ، مصر}

\section{طاهر مصطفى حامد يوسف}

و أر اضى قاحلة و المناطق العمر انية و البحيــر ات و الكثبـــان

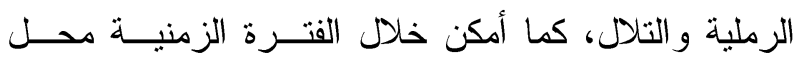

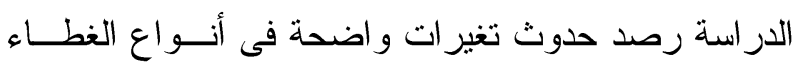

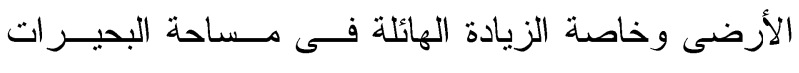

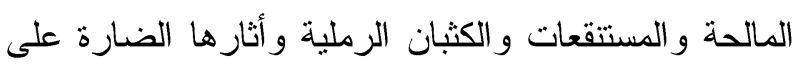

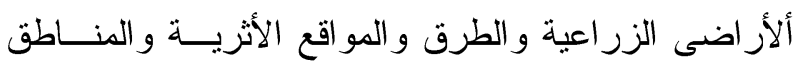

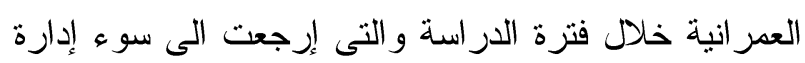



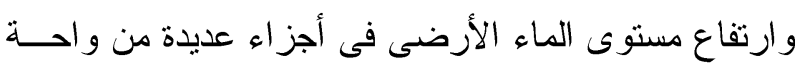

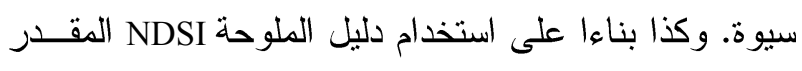

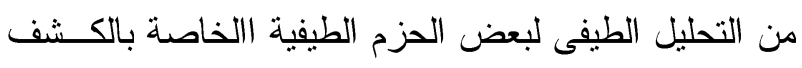

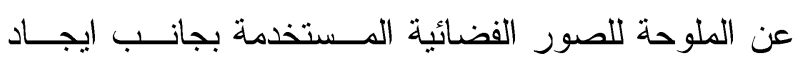
Regration analysis العلاقة الكمية لتحليل الانحدار المتعدد بين قيم التوصيل الكهربى EC

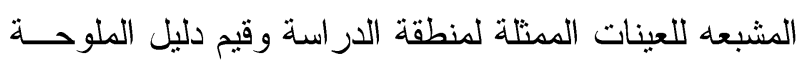
NDSI

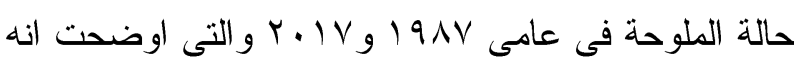

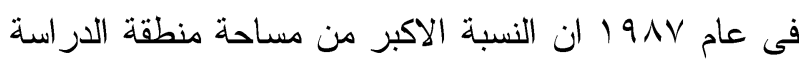

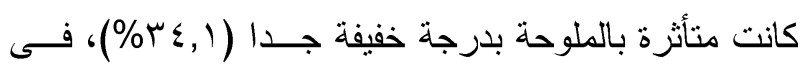

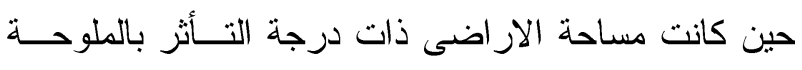

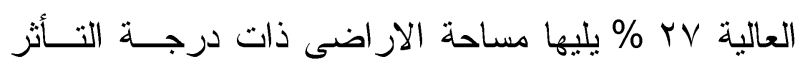

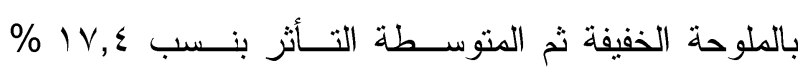


اعتبار أن باقى المساحة إما مغطاة بمياه البحير ات أو المبانى و التلال. كما اوضحت دراسة الخرائط المنتجة فـى عـى لــام

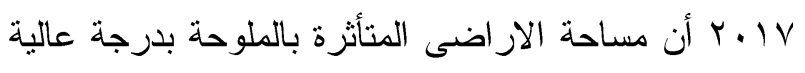

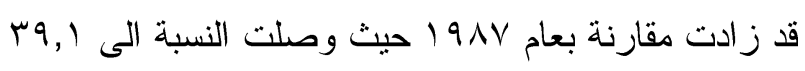
\% من المساحة الكلية لمنطقة الدراسة، فى حين أن مساحة
يعتبر رصد التغيرات فى مظـــاهر الغطــــاء الأرضــى و استخدامات الأراضى بشكل مستمر ودقيق ذو أهمية كبيرة

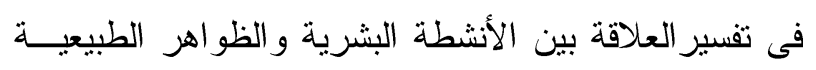

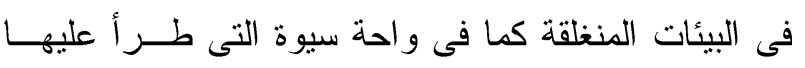

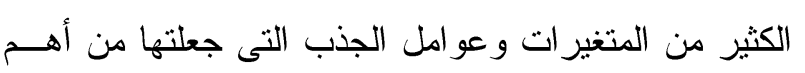



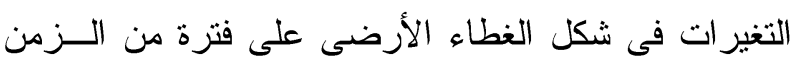
كما يعتبر رصد التغير الكمى فى ملوحة التزبة بهدف تقليل

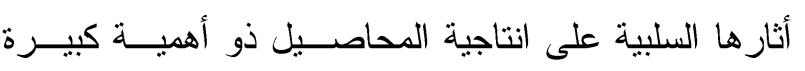

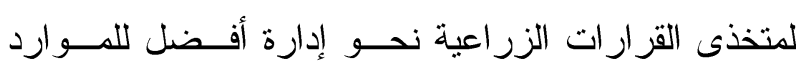

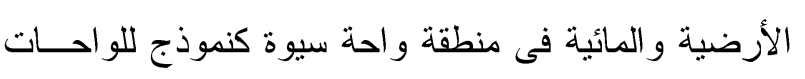



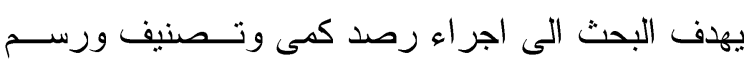

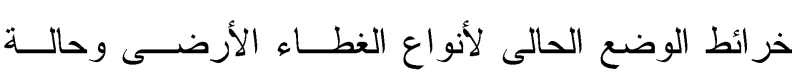

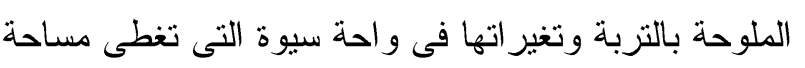

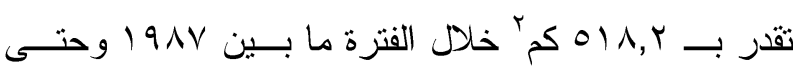

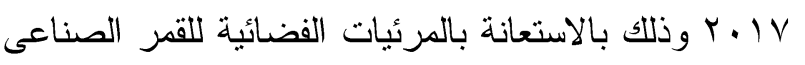




التحليل المعملى و الأحصائى. وبناءا على استخدام التحليل الطيفى البصرى و الرقـــى المتقدم و الغطاء الخضرى NDVI للمـــئيتين الفــــائيتين

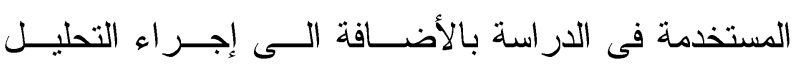

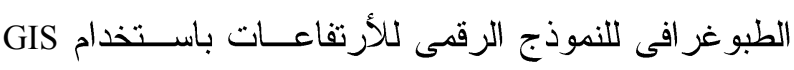



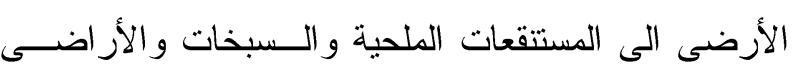
المنزرعة وأرضى بها غطاء خضرى طبيعى (الحـشائش) 


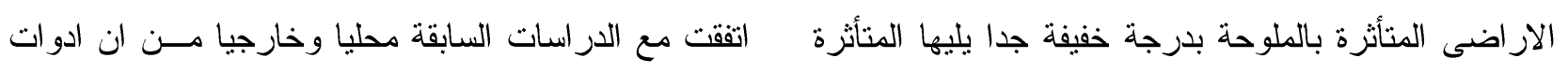

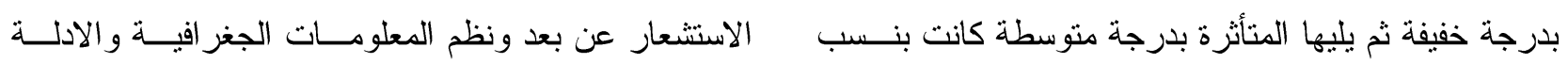

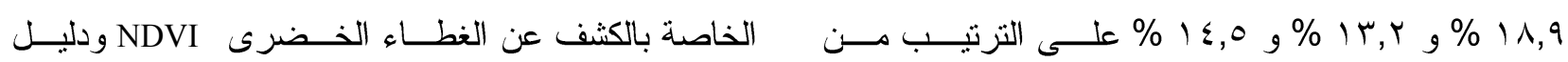

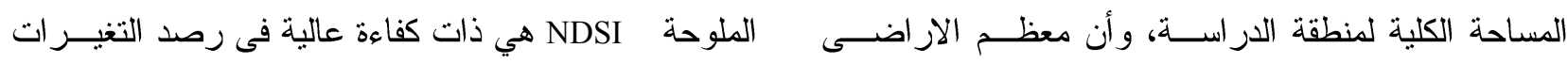

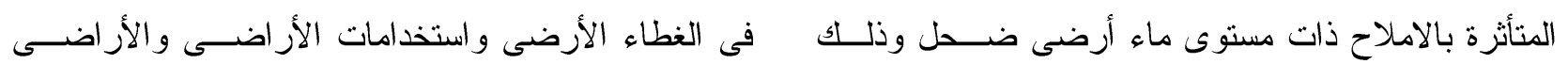



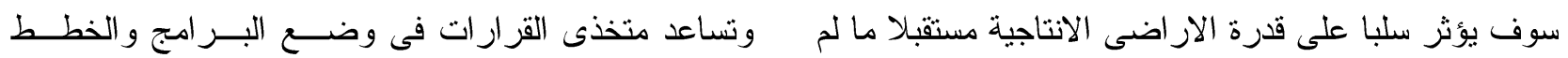
يتم التدخل على اساس علمى للحد من تفاقم المشاكل ووضع التنموية المستدامة.

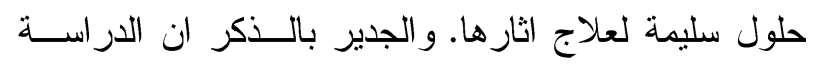

